\title{
PENGARUH WORK FROM HOME TERHADAP KINERJA KARYAWAN DI MASA PANDEMI COVID 19
}

\author{
Lilis Sulastri \\ UIN Sunan Gunung Djati Bandung \\ Email: lilis.sulastri@uinsgd.ac.id
}

\begin{abstract}
Abstrak
Bekerja dari rumah (WFH) telah diterapkan di PT. Sakti Mandiri Gifari Makassar untuk mengetahui dampak WFH terhadap kinerja pegawai dan prosedur kinerja pegawai selama wabah influenza. Metodologi deskriptif kuantitatif digunakan dalam penelitian ini, dan sampel sebanyak 113 responden dari PT. Sakti Mandiri Gifari Makassar dipilih menggunakan metodologi random sampling untuk penelitian ini. Berdasarkan hasil analisis uji statistik deskriptif, uji validitas data, dan analisis regresi, dapat disimpulkan bahwa Work From Home (WFH) memiliki keterkaitan yang tinggi dengan kinerja karyawan $(\mathrm{t}=4,757)$ dan memiliki hubungan yang tinggi secara statistik pengaruh yang signifikan $(p=0,000)$. Akibatnya, dalam analisis ini, kami menerima Ha dan menolak $\mathrm{H}_{\mathrm{O}}$, yang menunjukkan bahwa variabel WFH (X) berpengaruh signifikan secara statistik terhadap variabel kinerja karyawan (Y).
\end{abstract}

Kata Kunci: Kinerja, Karyawan, Bekerja dari Rumah.

\begin{abstract}
Working from home (WFH) has been implemented at PT. Sakti Mandiri Gifari Makassar in order to investigate the impact of WFH on employee performance and employee performance procedures during the influenza epidemic. The descriptive quantitative methodologies were used in this study, and a sample of 113 respondents from PT. Sakti Mandiri Gifari Makassar was selected using a random sampling methodology for the study. On the basis of the findings of the descriptive statistical test analysis, the data validity test, and the regression analysis, it can be concluded that Work from Home (WFH) has a high link with employee performance ( $t$ $=4.757)$ and has a statistically significant effect $(p=0.000)$. As a result, in this analysis, we accept $\mathrm{Ha}$ and reject $\mathrm{H}_{O}$, which indicates that the WFH variable $(X)$ has a statistically significant effect on the employee performance variable $(Y)$.
\end{abstract}

Keywords: Performance, Employees, Working from Home.

\section{A. PENDAHULUAN}

Sebuah pandemi global yang dikenal sebagai Corona Virus Disease telah membuat takut pemerintah di seluruh dunia baru-baru ini (Covid-19). Akibat dari serangan virus ini, kehidupan manusia di seluruh dunia telah terkena dampak yang signifikan, dengan perubahan pada bidang-bidang penting seperti kesehatan, ekonomi, politik, dan keamanan semua terjadi (Rosita, 2020). Selain itu, Covid-19 telah berkembang menjadi risiko keamanan yang sangat besar bagi semua perusahaan di seluruh dunia. Akibatnya, prosedur tempat kerja dan interaksi manusia telah bergeser. Melarang karyawan untuk bekerja di meja mereka dan berkumpul di sebuah ruangan adalah pendekatan mengubah praktik kerja yang dipermasalahkan (Salain dkk, 2020). Bukannya menyabotase produktivitas, larangan ini dimaksudkan untuk menghentikan penyebaran Covid-19 yang menyebabkan peningkatan jumlah korban di Indonesia. WFH telah 
dibahas dan dipelajari oleh para sarjana di seluruh dunia selama sepuluh tahun sebelumnya, tetapi fenomena di seluruh dunia ini mulai muncul pada saat serangan COVID-19 dan menjadi strategi alternatif bagi banyak bisnis (Mungkasa, 2020).

Terlepas dari kenyataan bahwa Work From Home (WFH) tidak lagi menjadi pilihan bagi pegawai pemerintah yang bertugas dalam peran pengabdian masyarakat, banyak perusahaan di Indonesia tetap memberikan kesempatan kepada karyawan untuk bekerja dari rumah (Darmawan \& Atmojo, 2020). Selain itu, kemajuan teknologi informasi selama revolusi industri saat ini telah mengubah berbagai metode kerja dan budaya organisasi, mengharuskan perusahaan yang mengalami perubahan di semua bidang untuk mengembangkan strategi untuk mendapatkan keunggulan kompetitif (Suaedi, 2019). Dengan kemajuan teknologi dan informasi, tidak hanya berdampak pada perusahaan, tetapi juga pada gaya hidup dan kehidupan sosial masyarakat. Akibatnya, banyak bisnis sekarang memprioritaskan layanan masyarakat. Sebagai akibat dari pergeseran sikap yang dibawa oleh kemajuan teknologi, ketidaksetaraan gender di berbagai bidang tidak lagi dianggap sebagai batasan kualifikasi dan spesifikasi tetapi lebih sebagai indikator fokus perusahaan pada kemampuan dan pengetahuan sumber daya manusia (Aithal \& Kumar, 2016).

Transformasi dramatis adalah realitas mutlak dan tak terhindarkan bagi sebagian besar bisnis di era Revolusi Industri 4.0. (Novitasari dkk, 2020). Untuk menjawab tantangan tersebut, suka atau tidak suka perusahaan membutuhkan strategi yang dapat berkembang dan berinovasi. untuk memastikan bahwa perusahaan yang dikembangkan selama bertahun-tahun tidak hancur oleh perubahan zaman dan terhambat dalam pertumbuhannya (Asbari, 2020). Perusahaan harus sudah memiliki road map yang terintegrasi dengan baik untuk menunjukkan potensi pertumbuhan masa depan perusahaan secara jelas. Persiapan untuk perubahan adalah strategi penting dalam organisasi mana pun, tetapi sangat penting dalam perusahaan komersial global. Bersaing dalam skala internasional saat ini membutuhkan adaptasi yang konstan dari setiap pemangku kepentingan industri (Yuwono dkk, 2020).

Dalam penelitian kali ini, PT. Sakti Mandiri Gifari sebagai objek penelitian Kinerja Karywan dengan menggunakan metode bekerja jarak dari rumah juga menerapkan sistem WFH, yang dalam penerapannya perusahaan tersebut mengacu pada lingkungan serta kondisi lokal letak geografis berdirinya perusahaan. Bahkan Kota Makassar telah mencapai titik tertinggi jumlah kasus terkonfirmasi positif di Sulawesi Selatan per 25 Juli 2021, tercatat bertambah 880 pasien baru, dengan akumulasi pasien sebanyak 77.248 kasus, dan sulawesi selatan berada di perinhgkat ke-12 secara nasional sesuai data media harian Covid-19 Kemenkes. Sementara data harian perkembangan info Satgas Covid-19 Provinsi Sulawesi Selatan, dilansir per 24 Juli 2021tercatat kasus baru mencapai 815 pasien dari jumlah spesimen yang diperiksa sebanyak 4.188 sampel dengan total akumulasi 76.368 kasus (www.antaranews.com). 


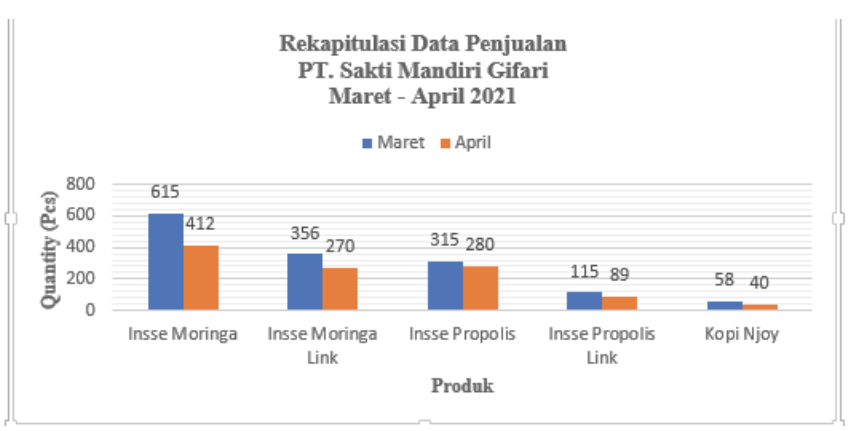

Gambar 1. Data Penjualan

Sumber: PT. Sakti Mandiri Gifari

Dari data di atas dapat diartikan bahwa total penjumlahan setiap produk yang terjual selama pandemi Covid-19 mengalami penurunan setiap bulannya. Meskipun terkesan fluktuatif pada tri wulan terakhir, total omzet yang biasanya diperoleh di angka Rp500.000.000.-, kini perusahaan tidak lagi mendapatkannya. Hal ini membuat PT. Sakti Mandiri Gifari membuat strategi agar bisa bangkit dan menghidupi ratusan karyawannya, dan salah satu sistem pekerjaan yang diterapkannya ialah menggunakan sistem bekerja dari rumah (work from home).

\section{B. TINJAUAN PUSTAKA}

\section{Manajemen Sumber Daya Manusia}

Manajemen sumber daya manusia, kadang-kadang dikenal sebagai MSDM, adalah metode untuk mengelola sumber daya manusia organisasi, termasuk merekrut, melatih, menilai, memberi kompensasi, dan mengevaluasi setiap individu karyawan (Simamora, 2004). Manajemen sumber daya manusia didefinisikan oleh Mondy \& Neo (1993) sebagai penggunaan sumber daya manusia untuk memenuhi tujuan organisasi. Manajemen sumber daya manusia pada dasarnya adalah pengelolaan aset manusia sedemikian rupa sehingga dapat terus meningkat produktivitasnya.

\section{Work From Home}

Work From home adalah kata yang mengacu pada menyelesaikan pekerjaan yang biasanya dilakukan di kantor dari rumah. Akibatnya, karyawan bebas menghindari pertemuan tatap muka dengan rekan kerja di kantor (Ashal, 2020). Menggunakan munculnya "gelombang ketiga," Alvin Toffler mengusulkan konsep bekerja dari jarak jauh (telework) dalam tiga tahap pada tahun 1980. Mengikuti upaya untuk mengurangi perjalanan dan konsumsi energi pada tahun 1970an dan 1980an, bekerja dari rumah menjadi lebih populer sebagai hasilnya. Hal ini memungkinkan karyawan untuk menjaga keseimbangan antara pekerjaan dan kehidupan keluarga sambil juga mengatasi kekurangan tenaga kerja terampil. Ketika ekonomi pinggiran kota tumbuh dan menjadi lebih terintegrasi dengan pusat kota, desain tempat kerja dan manajemen fasilitas menjadi semakin penting untuk membantu karyawan tetap produktif dan efisien (Mungkasa, 2020).

\section{Kinerja}

Kinerja diukur dengan kualitas dan kuantitas pekerjaan yang diselesaikan oleh seorang karyawan saat melaksanakan tanggung jawab dan kewajiban yang diberikan kepadanya. 
Kinerja ditentukan oleh kualitas dan jumlah pekerjaan yang dilakukan seorang pekerja saat memenuhi tugas yang telah dipercayakan kepadanya (Mangkunegara, 2002).

\section{METODE}

Dalam penelitian ini menggunakan model penelitian kuantitatif deskriptif. Peneliti menyebarkan kuesioner secara online kepada 113 karyawan PT. Sakti Mandiri Gifari sebagai sampel secara online dengan alat ukur penilaian skala likert (ordinal), dari kuisioner yang disebarkan kemudian didapat data yang diolah menggunakan aplikasi SPSS versi 25.

\section{HASIL DAN PEMBAHASAN}

Responden yang mengisi kuesioner penelitian ini merupakan seluruh karyawan yang bekerja di PT. Sakti Mandiri Gifari. Untuk profil responden pada penelitian ini, peneliti membagi responden berdasarkan jenis kelamin dan tingkat pendidikan. Berdasarkan jenis kelamin responden, dapat diketahui bahwa jumlah laki-laki yang sedang bekerja sebagai karyawan berjumlah $42 \%$ atau 47 orang dari total 113 responden, dan jenis kelamin perempuan sebanyak $58 \%$ atau 66 orang dari total 113 responden.

\section{Tabel 1. Uji Regresi Linear Model Summary}

\begin{tabular}{|l|l|r|r|r|}
\multicolumn{5}{c|}{ Model Summary } \\
\hline Model & R & R Square & Adjusted R Square & Std. Error of the Estimate \\
\hline 1 & $.412^{\mathrm{a}}$ & .169 & .162 & 4.465 \\
\hline
\end{tabular}

a. Predictors: (Constant), WFH

Sumber: Data Diolah Peneliti, 2021

Dengan bantuan tabel di atas, Anda dapat memahami besarnya nilai korelasi (R), yaitu 0,412 , dan besarnya pengaruh variabel yang mempengaruhi (disebut koefisien determinasi), yang diperoleh dengan rooting kuadrat nilai korelasi (R). Berdasarkan output tersebut diperoleh koefisien determinasi $\left(\mathrm{R}^{2}\right)$ sebesar 0,169 yang menunjukkan bahwa variabel (WFH) memiliki pengaruh sebesar 16,9 persen terhadap variabel (kinerja karyawan), sedangkan pengaruhnya terhadap variabel lainnya dapat diabaikan (tidak berpengaruh).

Tabel 2. Uji Regresi Linear Model Annova

"
\begin{tabular}{|l|l|r|r|r|r|r|}
\hline \multicolumn{1}{|l|}{ Model } & Sum of Squares & \multicolumn{1}{c|}{$\mathrm{df}$} & Mean Square & $\mathrm{F}$ & Sig. \\
\hline \multirow{3}{*}{1} & Regression & 451.021 & 1 & 451.021 & 22.628 & $.000^{\mathrm{b}}$ \\
\cline { 2 - 8 } & Residual & 2212.431 & 111 & 19.932 & & \\
\cline { 2 - 8 } & Total & 2663.451 & 112 & & & \\
\hline
\end{tabular}

a. Dependent Variable: Kinerja

b. Predictors: (Constant), WFH

Sumber: Data Diolah Peneliti, 2021

Di sini, kita akan menguji hubungan substansial (signifikan) antara variabel WFH (X) dan Variabel Kinerja Karyawan (Y). Jika F hitung $=22,628$, maka model regresi dapat digunakan untuk memprediksi kinerja karyawan, dan tingkat signifikansi/probabilitas adalah $0,000<0,05$. Sebagai tindak lanjut, Anda dapat menjalankan tes lain untuk melihat apakah ada perbedaan yang signifikan secara statistik dalam t-hitung antara kedua kelompok:

$\mathbf{d f}=\mathbf{N}-\mathbf{K}-\mathbf{1}$ 


\section{Dimana:}

df : Degree of Freedom atau derajat kebebasan

$\mathrm{N} \quad$ : Jumlah sampel yang diteliti (113)

$\mathrm{K} \quad$ : Jumlah Variabel Bebas

Maka:

df $\quad=113-1-1$

$=111$

Sehingga dihasilkan nilai df sebesar 111 maka nilai t tabel dengan tingkat signifikansi $5 \%$ atau 0,05 adalah 1,662 .

Tabel 3. Tabel Nilai Koefisien

Coefficients $^{\mathrm{a}}$

\begin{tabular}{|c|c|c|c|c|c|c|}
\hline \multirow{2}{*}{\multicolumn{2}{|c|}{ Model }} & \multicolumn{2}{|c|}{$\begin{array}{c}\text { Unstandardized } \\
\text { Coefficients }\end{array}$} & \multirow{2}{*}{$\begin{array}{c}\begin{array}{c}\text { Standardized } \\
\text { Coefficients }\end{array} \\
\text { Beta } \\
\end{array}$} & \multirow[b]{2}{*}{$\mathrm{t}$} & \multirow[b]{2}{*}{ Sig. } \\
\hline & & $B$ & Std. Error & & & \\
\hline \multirow[t]{2}{*}{1} & (Constant) & 27.377 & 2.773 & & 9.873 & .000 \\
\hline & WFH & .444 & .093 & .412 & 4.757 & .000 \\
\hline
\end{tabular}

a. Dependent Variable: Kinerja

Sumber: Data Diolah Peneliti, 2021

Karena nilai Konstanta (a) pada Kolom B adalah 27,377 dan nilai WFH (b) adalah 0,444 pada Tabel Koefisien, maka persamaan regresi dapat dinyatakan sebagai berikut: $\mathrm{Y}=$ $27,377+0,444 X$. Koefisien $\mathrm{b}$ disebut sebagai koefisien arah regresi dan mencerminkan ratarata perubahan variabel Y untuk setiap unit perubahan variabel X. Ketika b positif, perubahan ini positif; ketika $b$ negatif, perubahan ini negatif. Dengan demikian, persamaan ini dapat diartikan sebagai berikut:

a. Jika tidak ada nilai WFH maka nilai kinerja pegawai adalah 27,377.

b. Koefisien regresi $\mathrm{X}$ sebesar 0,444 menunjukkan bahwa penambahan satu nilai WFH meningkatkan nilai kinerja karyawan sebesar 0,444.

Terlihat dari hasil di atas, ketika t hitung $=4,757$ dengan taraf signifikansi 0,000 0,05 maka H0 ditolak dan Ha diterima, hal ini menunjukkan bahwa terdapat pengaruh yang substansial (signifikan) variabel WFH (X) terhadap kinerja karyawan (Y).

\section{Pembahasan}

Dari hasil analisis yang telah dilakukan peneliti tentang pengaruh variabel Work from Home (X) terhadap Kinerja Karyawan (Y) terbukti berpengaruh kuat dan signifikan. Hal ini ditunjukan oleh hasil uji hipotesis melalui uji parsial dan statistika yang memperlihatkan nilai t hitung lebih besar dari t tabel $(4,757>1,662)$ dan nilai signifikansi lebih kecil dari standar yang telah ditetapkan $(0,000<0,05)$ yang berarti menerima Ha dan menolak H0.

Selanjutnya, peneliti dapat menyimpulkan terkait kinerja karyawan di masa pandemi Covid-19 merasa cukup efektif dan efisien, mengingat kebijakan pemerintah yang ada seperti PSBB, PPKM dan lain sebagainya mengharuskan perusahaan melakukan WFH untuk sektor esensial. Hal itu, dibuktikan dengan ditemukannya pengaruh positif WFH terhadap kinerja karyawan sebesar 16,9\%, sisanya dipengaruhi oleh faktor lain yang belum diketahui oleh peneliti.

Hasil penelitian ini sejalan dengan penelitian sebelumnya yang dilakukan oleh Irmayani Nasution, Zulhendry \& Raina Rosanti dalam Jurnal Volume 1 No 1 (2020) dengan judul penelitian Pengaruh Work From Home Terhadap Kinerja Karyawan BPKP (Badan 
Pengawasan Keuangan dan Pembangunan) Provinsi Sumatra Utara yang menunjukan adanya hubungan kuat dan berpengaruh positif terhadap kinerja karyawan yang bekerja di kantor tersebut. Timbal \& Mustabsat percaya bahwa perusahaan yang membantu Work From Home (WFH) akan memiliki produksi dan kinerja yang lebih tinggi. Penelitian ini mendukung keyakinan mereka. Sedangkan kinerja pegawai sesuai dengan penilaian Hasibuan, diasumsikan bahwa jika kinerja setiap individu atau pegawai baik maka kinerja perusahaan atau organisasi juga akan baik.

Terkait praktik kerja, perusahaan yang bersangkutan "melarang" karyawan bekerja di kantor atau berkumpul di dalam ruangan, memaksa mereka bekerja dari rumah (WFH) atau dari tempat kerja mereka. dengan kata lain, dengan mendelegasikannya ke pekerja jarak jauh (Mustajab et al., 2020). Aturan ini tidak dimaksudkan untuk menghambat produktivitas; alihalih, itu ada untuk menghentikan penyebaran virus corona, yang telah terdeteksi. Ketika Program Pangan Dunia mengalami masalah, itu karena filosofi WFH tidak sepenuhnya tertanam dalam organisasi (Mustajab et al., 2020).

\section{E. KESIMPULAN}

Dari hasil penelitian yang dilakukan tentang pengaruh Work from Home terhadap kinerja karyawan pada PT Sakti Mandiri Gifari selama pandemi COVID 19 dapat disimpulkan bahwa variabel Work from Home (X) mempunyai pengaruh yang signifikan terhadap kinerja karyawan. Hal ini dapat dilihat dengan t hitung $=4,757>0,05$ dengan signifikansi 0,000. Selanjutanya didapatkan juga bahwa variabel Work from homememberikan pengaruh 16,9\% terhadap kinerja karywan sementara sisanya dipengaruhi variabel lain yang tidak dibahas pada penelitian ini.

\section{DAFTAR PUSTAKA}

Aithal, P. S., \& Kumar, P. M. (2016). Organizational Behaviour In 21st Century-'Theory A'for Managing People For Performance. IOSR Journal of Business and Management (IOSRJBM), 18(7), 126-134.

Asbari, M. D. (2020). Mempertahankan Kinerja Karyawan di Masa Pandemi Covid-19: Studi Kasus pada Industri Ritel. JMK (Jurnal Manajemen dan Kewirausahaan), 5 (3),, 183 203.

Ashal, R. A. (2020). Pengaruh Work From Home terhadap Kinerja Aparatur Sipil Negara di Kantor Imigrasi Kelas I Khusus TPI Medan. Jurnal Ilmiah Kebijakan Hukum, 14(2), 223-242.

Darmawan, E., \& Atmojo, M. E. (2020). Kebijakan Work From Home bagi Aparatur Sipil Negara di Masa Pandemi Covid-19. TheJournalish: Social and Government, 1(3), 9299.

Mangkunegara, A. P. (2002). Manajemen Sumber Daya Manusia Perusahaan. Bandung : PT. Remaja Rosdakarya.

Mondy, R. W., \& Neo, R. M. (1993). Human Resource Management. Boston: Allyn \& Bacon. Mungkasa, O. (2020). Bekerja dari Rumah (Working From Home/WFH): Menuju Tatanan Baru Era Pandemi COVID 19. Jurnal Perencanaan Pembangunan: The Indonesian Journal of Development Planning, 4(2), 126-150.

Novitasari, D., Asbari, M., Sutardi, D., Gazali, G., \& Silitonga, N. (2020). Pengaruh Kesiapan untuk Berubah dan Efektivitas Kepemimpinan Transformasional terhadap Kinerja 
Karyawan di Masa Pandemi Covid-19. Value: Jurnal Manajemen Dan Akuntansi, 15(2), 22-37.

Rosita, R. (2020). Pengaruh Pandemi Covid-19 Terhadap UMKM Di Indonesia. Jurnal Lentera Bisnis, 9(2), 109-120.

Salain, P. P. P., Adiyadnya, M. S. P., \& Rismawan, P. A. E. (2020). Studi eksplorasi dampak work from home terhadap kinerja karyawan di masa pandemi Covid-19 pada bumn di wilayah Denpasar. Jurnal Ilmiah Satyagraha, 3(2), 19-27.

Simamora, H. (2004). Akuntansi Manajemen. Jakarta: Salemba Empat.

Suaedi, F. (2019). Dinamika Manajemen Strategis Sektor Publik di Era Perubahan. Airlangga University Press.

Yuwono, T., Wiyono, N., Asbari, M., Novitasari, D., \& Silitonga, N. (2020). Analisis Pengaruh Efektivitas Kepemimpinan Transformasional dan Kesiapan untuk Berubah terhadap Kinerja Karyawan Wanita di Masa Pandemi Covid-19. Jurnal Ilmiah Mahasiswa Ekonomi Manajemen, 5(3). 